\title{
Floristic Composition, Distribution, and Association of Pandanus (Pandanaceae) in The Bukit Duabelas National Park Jambi
}

\author{
Dimas Prasaja \\ University of Pakuan, Bogor, West Java, Indonesia \\ Corresponding author: prasajadimas@gmail.com
}

\begin{abstract}
Pandanus species has natural fibers which are suitable for plaiting, and other necessities, mythological rituals, and building materials for the SAD (Suku Anak Dalam) community that live in the Bukit Duabelas National Park area. The presence of pandanus in the forest is increasingly threatened if conservation efforts are not carried out. The study aimed to examine floristic composition, distribution patterns, and association of pandanus species in Bukit Duabelas National Park. The method used was a striped line, with a plot of 35 sample plots. To find out the dominant type of IVI (important value index), it was analyzed based on the density, frequency, and dominance of sample plot enumeration. Distribution patterns were analyzed using the Morisita Index, while association patterns used contingency tables and Chi-square tests. The distribution pattern showed that there were two species of Pandanus (Benstonea kurzii and Benstonea atrocarpa) growing in groups and three species (Pandanus labyrinthicus, Pandanus furcatus, and Pandanus immersus) had a population that grew evenly. From the Chi-square test, it turns out the most plants in the observation area are not associated with Pandanus species except Litsea sp1 (associated with Benstonea kurzii, IVI >10\%).
\end{abstract}

Keywords: Pandanus, floristic compositio,; distribution pattern, association.

\section{Introduction}

Administratively, Bukit Duabelas National Park (BDNP) is included in four regencies, namely: Sarolangun, Bangko, Batanghari, and Tebo Regencies. This area is a lowland forest with a hilly geographical elevation of 50-200 m above sea level. This area is critical to maintaining water use because it acts as a catchment and water absorption area (Wiriadinata, 1997). The Bukit Duabelas National Park area is a place where the Anak Dalam Tribe (ADT) resides, commonly called Orang Rimba (Setyowati, 2003). The life of the SAD community, in general, is still classified as traditionally relying on forest products as a source of fulfillment of clothing, food and shelter needs. The existence of forest products is inseparable from the dependence of the SAD community which is used for daily life to support their life and economic needs. One of the ingredients used for making handicrafts is woven from pandanus leaves.

Pandanus species have begun to experience a decline in population because harvesting pandanus is done wildly in nature and has not been cultivated. Mairida et al., (2014) revealed that pandan leaves were used as material for making mats. In other areas, Rahayu et al. (2008), reported that the Ujung Kulon community cultivated tanned pandanus as a source of handicraft raw materials to improve their economy. It is essential to assess the characteristics of vegetation, distribution patterns, and associations to see how the ecological conditions of the pandanus that has high 
utilization rates but there has been no cultivation effort, so it is feared that the species is extinct. Community characteristics of an environment are diversity. The more diverse the biotic components, the higher the diversity. Conversely, the less diversified, the lower the diversity (Riberu, 2002).

Such vegetation studies are one form of early conservation of species in their natural habitat, and the government can make policies in the preservation of these species in nature. Vegetation studies conducted in this area aimed to explore information about the conditions of several types of pandanus in natural forests, including floristic compositions that influence their presence in nature, distribution patterns, and associations with other species in the habitat.

\section{Material and Method}

This research was conducted in the utilization zone of BDNP in Air Hitam Subdistrict, Sarolangun Regency, Jambi Province. Plant identification was carried out at the Herbarium Bogoriense Research Center for Biology Indonesian Institute of Sciences Cibinong. The material in this study was pandanus in the BDNP use zone. The tools used were digital cameras, measuring tape, ropes, GPS, compass, laptops, and stationery.

\subsection{Data Collection}

The study was carried out by sampling a plant using a grided method bypassing the river, and climbing the hills. Sampling plots were made on the designated lines with sizes $(2 \times 2) \mathrm{m}^{2},(5 \times 5) \mathrm{m}^{2},(10 \times 10) \mathrm{m}^{2}$, and $(20 \times 20) \mathrm{m}^{2}$ for 35 plots. The plots were determined after the presence of several types of pandanus was used by the SAD in that location. For each plot, all the plants, species name, and stem diameter were recorded. In each of these plots is also made a plot of size $(2 \times 2) \mathrm{m}^{2}$ for seedlings, $(5 \times 5) \mathrm{m}^{2}$ for saplings $(10 \times 10) \mathrm{m}^{2}$ for the pole, and $(20 \times 20) \mathrm{m}^{2}$ for the tree. The enumeration in each plot was performed simultaneously. This method is specifically used in sampling lower vegetation types, and upper vegetation (Susilowati, et al., 2019).

The criteria for each strata are as follows Seedling is individual which $<1.5 \mathrm{~m}$, Sapling is individual which $\geq 1,5 \mathrm{~m}$, Pole is individual with $10-19 \mathrm{~cm}$ diameter ( $\mathrm{dbh}$ ), and Tree is individual with a diameter of $\geq 20 \mathrm{~cm}(\mathrm{dbh})$. In each plot, the diameter at breast height and the total height of each individual species were recorded (Pereki et al., 2013).

Besides, the Important Value Index (IVI) was also calculated to see the structure and position of several types of pandanus compared to other plant species in the region. The IVI value can be used as a parameter to reveal the importance of the study of species ecology in specific ecosystems (Setiawan and Narendra, 2012). Tulalessy (2012) explained that IVI values are calculated based on density, basal area and frequency of existence, in this case, the vegetation conditions that describe the composition of its constituent tree species and dominant species are analyzed using the following formula (Mueller-Dombois, \& Ellenberg, 1975), namely for seedling and sapling phases: RF = (frequency of species $\mathrm{i} / \mathrm{sum}$ frequencies of all species) $\times 100, \mathrm{RD}=$ (number of 
individuals of species $\mathrm{i} /$ total number of individuals $) \times 100, \mathrm{RDo}=($ total basal area for species i/total basal area of all species) (Ismail et al., 2017).

\subsection{Data Analysis}

Vegetation data in the form of floristic composition obtained was and then analyzed to determine the distribution pattern of pandanus plants, and their association with other plants. To obtain the pattern of distribution of pandanus, a variety ratio calculation is performed (Pereki et al., 2013), as follows:

$$
\bar{X}=\frac{\sum x_{i} \cdot f_{i}}{\sum f_{i}}=\frac{n}{N} \quad S^{2}=\frac{\sum\left(x_{i}^{2} \cdot f_{i}\right)-\bar{X} \cdot n}{N-1}
$$

Description $x i=$ number of individuals; $f i=$ frequency of the number of individuals found; $\bar{x}=$ average value (number of individuals/total plot); $\mathrm{n}=$ total number of individuals; $\mathrm{N}=$ total plot; and $\mathrm{S}^{2}=$ Variance.

Dispersion Index (ID): $\mathbf{I D}=\frac{S^{2}}{\bar{X}}$

where, if the value ID $>1$, which means spread in groups; ID $<1$, which means spread evenly, and ID = 1, which means spread randomly.

Determination of whether there is an association between pandanus and other plant species is based on the main constituent type, which has IVI P10\% using the $2 \times 2$ Contingency Table and Chi-square $\left(X^{2}\right)$ value (Ludwig, \& Reynolds, 1988). If the value of $\mathrm{X}^{2}$ calculation $>\mathrm{X}^{2}$ table means an association occurs, whereas if $\mathrm{X}^{2}$ calculation $<\mathrm{X}^{2}$ table means no association occurs. Table values with free degrees 1 at the $5 \%$ level are 3.84. As for calculating $\mathrm{X}^{2}$ calc with the help of the matrix in Table 1 as follows.

Table 1. $2 \times 2$ contingency for association calculation

\begin{tabular}{lccc}
\hline Species / site $\boldsymbol{A}$ & \multicolumn{2}{c}{ Species / site B } & \multirow{2}{*}{ Total } \\
\cline { 2 - 3 } & Presence (Positive) & Absence (Negative) & \\
\hline Presence (Positive) & $\mathrm{a}$ & $\mathrm{b}$ & $\mathrm{a}+\mathrm{b}$ \\
Absence (Negative) & $\mathrm{c}$ & $\mathrm{d}$ & $\mathrm{c}+\mathrm{d}$ \\
Total & $\mathrm{a}+\mathrm{c}$ & $\mathrm{b}+\mathrm{d}$ & $\mathrm{N}=\mathrm{a}+\mathrm{b}+\mathrm{c}+\mathrm{d}$ \\
\hline
\end{tabular}

Expectation value for $a, b, c$, and $d$ is:
$\mathrm{E}(\mathrm{a})=(\mathrm{a}+\mathrm{b})(\mathrm{a}+\mathrm{c}) / \mathrm{N}$
$\mathrm{E}(\mathrm{b})=(\mathrm{a}+\mathrm{b})(\mathrm{b}+\mathrm{d}) / \mathrm{N}$
$E(c)=(c+d)(a+c) / N$
$\mathrm{E}(\mathrm{d})=(\mathrm{c}+\mathrm{d})(\mathrm{b}+\mathrm{d}) / \mathrm{N}$

Test criteria are carried out with the following equation:

$$
X^{2}=\frac{\sum_{i=1}^{n}(O-E)^{2}}{E}
$$


The results of the calculation of tree species associations that have an Important Value Index $\geq 10 \%$. Furthermore, these results are tested by calculating the Association Index (Ludwig, \& Reynold, 1988) as follows:

$$
\mathrm{Oi}=\frac{\mathrm{a}}{\sqrt{\mathrm{a}+\mathrm{b}} \cdot \sqrt{\mathrm{a}+\mathrm{c}}}
$$

Where, $a$ is the number of species presence at both sites $\mathrm{A}$ and $\mathrm{B} ; b$ is the number of species presence at site A but not $B$; $c$ is the number of species presence at site $B$ but not $\mathrm{A}$; and $d$ is the number of paired absences at both sites $\mathrm{A}$ and $\mathrm{B}$.

\section{Results and Discussion}

\subsection{Species Diversity}

An analysis of the horizontal structure was conducted based on the parameters of density, frequency, dominance and cover value, reflecting the reality of the spatial distribution of populations, and distinguishing populations in the context of the ecosystem. Floristic analyses have revealed the diversity of species that compose the arboreal stratum of the forest, and the present research work is focused on this subset of the plant population (Amaral et al., 2015). Exploration results found six species of pandanus (Pandanaceae) divided into two different genera, namely Benstonea and Pandanus. The Benstonea genus consists of Benstonea atrocarpa (Griff.) Callm \& Buerki and Benstonea kurzii (Merr.) Callm. \& Buerki. While Pandanus consists of Pandanus labyrinthicus Kurz ex. Miq, Pandanus immersus Ridl., Pandanus furcatus Roxb. and Pandanus amaryllifolius Roxb. These pandanus species were found scattered in several heights with almost normal conditions. This type of Pandanaceae is used by Orang Rimba (Suku Anak Dalam) for daily needs, handicrafts and traditional ritual related needs (Prasaja, 2015). The results of Keim's exploration (2011) show the discovery of several new pandanus species in Sumatra and Kalimantan. Benstonea is originally a member of the genus Pandanus subgenus Acrostrigma (Kurz) BC Stone by morphological character, but there is still confusion. Character of the vegetative organs of Benstonea is not much different from the characters of Pandanus (Rachma, 2017).

The important value index (IVI) is a quantitative parameter to express the level of mastery or importance of the role of species in the vegetation of an ecosystem. If the species IVI is of high value compared to other species in an ecosystem, the existence of this species dramatically influences the stability of the ecosystem. This is because it may be due to high density or even distribution or broader basal mastery of the area or combination of the two or all three (Ismail et al., 2017). The important value index in this region provides an overview of the types that dominate and density of plants in 
pandanus vegetation in BDNP. The density of the number of individual plants in each grow phase is shown in Figure 1.

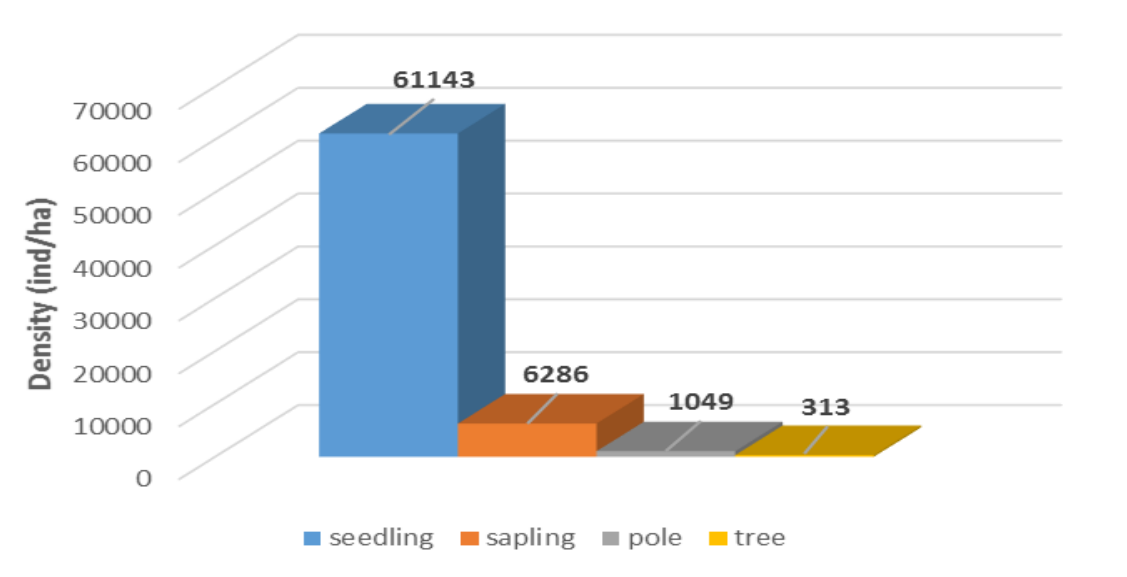

Figure 1. Total number of individuals of all plant species in each observation phase in BDNP

The abundance of pandanus species tended to be dominant in the sapling strata compared to seedling strata because of a large number of individuals was found in seedling strata. Population abundance is seen from the number of individuals per hectare. The results of vegetation analysis (Figure 1) show the proportion of individuals in each stratum. Seedling strata illustrate the highest density of individuals, while increasingly mature strata show a tendency for the number of individuals to decline with tree strata as the lowest proportion. The density index provides an overview of species composition in the community. When connected with the opinion of Pereki et al. (2013), the stated dominance is the type of diversity characterized by horizontal distribution and plant size. Besides, the dominance of a species at each level of vegetation indicates the survival of a species in a forest community. Species always dominant at each level are said to have high survival power.

\subsection{Floristic Composition of Seedling Strata on Pandanus Habitat}

The composition of the seedling strata species with the most families in the National Park consists of 44 families of 106 species. In the seedling strata Arecaceae family found more than 23 species. Furthermore, the list was followed by the Dipterocarpaceae family with 10 species, followed by the Burseraceae and Pandanaceae families, each of 5 species. Then followed by the families of Lauracecae, Leguminosae, and Melastomaceae, each of 4 species and so on. The list of Quantitative analysis for IVI (seedling phase) is presented in Table 2. 
Table 2. Quantitative analysis for IVI (seedling phase)

\begin{tabular}{|c|c|c|c|c|c|c|}
\hline No & Vernacular Name & Scientific Name & Family & $\begin{array}{l}\text { RD } \\
\text { (\%) }\end{array}$ & $\begin{array}{l}\text { RF } \\
\text { (\%) }\end{array}$ & $\begin{array}{l}\text { IVI } \\
(\%)\end{array}$ \\
\hline 1 & Balam merah & Palaquium gutta & Sapotaceae & 8.13 & 6.4 & 14.53 \\
\hline 2 & Mempisang & Mezzetiopsis sp & Annonaceae & 3.70 & 2.75 & 6.45 \\
\hline 3 & Kayu pisang & Garcinia sp2 & Clusiaceae & 3.52 & 2.75 & 6.27 \\
\hline 4 & Kedundung & $\begin{array}{l}\text { Santiria } \\
\text { dacryodifolia }\end{array}$ & Burseraceae & 2.04 & 4.21 & 6.25 \\
\hline 5 & Beyung & Canarium pilosum & Burseraceae & 3.70 & 2.2 & 5.90 \\
\hline 6 & Pandan gegas & Benstonea kurzii & Pandanaceae & 3.70 & 2.2 & 5.90 \\
\hline 7 & Balik angin & $\begin{array}{l}\text { Homalanthus } \\
\text { populneus }\end{array}$ & Euphorbiaceae & 3.52 & 2.2 & 5.72 \\
\hline 8 & Kabau & $\begin{array}{l}\text { Achidendron } \\
\text { bubalinum }\end{array}$ & Leguminosae & 3.52 & 2.2 & 5.72 \\
\hline 9 & Simpur jangkang & Dillenia eximia & Dilleniaceae & 3.52 & 2.2 & 5.72 \\
\hline 10 & Medang & Litsea firma & Lauraceae & 2.41 & 3.3 & 5.71 \\
\hline
\end{tabular}

Table 2 shows that Palaquium gutta species had the highest IVI of $14.53 \%$, followed by Mezetiopsis sp with IVI value of $6.45 \%$. Both of these species illustrate the best adaptability in this phase, both in terms of density and dispersion. This is supported by the ability of fecundity (the number of offspring produced) from both is very high, which is based on observations found the number of seedlings is very abundant, especially under the parent stand, including tree strata belonging to the family Dipterocarpaceae and Lauraceae. In this stratum, also found Benstonea kurzii species with IVI value of 5.9\%.

\subsection{Floristic Composition of Sapling Strata on Pandanus Habitat}

The composition of the species of sapling strata with the most families in the BDNP consists of 40 families of 95 species. In this stratum, the Arecaceae family consists of more than 23 species. Furthermore, the list is followed by the families of Pandanaceae, Lauraceae, and Rubiaceae, each of 5 species, followed by the family of Euphorbiaceae 4 species and so on. The list of Quantitative analysis for IVI (sapling phase) is presented in Table 3. 
Table 3. Quantitative analysis for IVI (sapling phase)

\begin{tabular}{llllllr}
\hline No & Vernacular Name & Scientific Name & Family & $\begin{array}{c}\text { RD } \\
\text { (\%) }\end{array}$ & $\begin{array}{r}\text { RF } \\
\text { (\%) }\end{array}$ & $\begin{array}{r}\text { IVI } \\
\text { (\%) }\end{array}$ \\
\hline 1 & Pandan gegas & Benstonea kurzii & Pandanaceae & 8.90 & 2.98 & 11.88 \\
2 & Mengkuang sabut & Benstonea atrocarpa & Pandanaceae & 7.45 & 2.24 & 9.69 \\
3 & Kayu kasai & Pometia pinnata & Sapindaceae & 4.55 & 3.87 & 8.42 \\
4 & Mengkuang tikus & Pandanus labyrinthicus & Pandanaceae & 5.82 & 1.79 & 7.61 \\
5 & Kayu arang & Diospyros buxifolia & Ebenaceae & 4.18 & 2.98 & 7.16 \\
6 & Mengkuang ladang & Pandanus furcatus & Pandanaceae & 4.73 & 2.24 & 6.97 \\
7 & Rotan cikoi & Daemonorops geniculata & Arecaceae & 2.55 & 3.43 & 5.98 \\
8 & Rotan sego putih & Calamus caesius & Arecaceae & 2.00 & 3.87 & 5.87 \\
9 & Rumbas tapo & Pandanus immersus & Pandanaceae & 3.64 & 1.34 & 4.98 \\
10 & Rotan udang/siuh & Korthalsia echinometra & Arecaceae & 2.55 & 2.24 & 4.79 \\
\hline
\end{tabular}

Note: $\mathrm{RD}=$ relative density, $\mathrm{RF}=$ relative frequency, $\mathrm{IVI}$ = important value index

The strata are dominated by five pandanus species (Table 3), which are used by Orang Rimba as raw material for making woven mats, chopsticks, and traditional rituals. B. kurzii is the highest IVI plant $(11.88 \%)$ in sapling strata, then B. atrocarpa with IVI (9.69\%), Pometia pinnata with IVI (8.42\%), P. labyrinthicus with IVI (7.61\%). B. kurzii and B. atrocarpa are belonging to the Pandanaceae family have small IVI differences. From field observation results, this species lives in groups and mostly grows in muddy waters and swamps in the BDNP forest, but the location of other pandanus species is very far and has entered the core zone. In this stratum, the Pometia pinnata has better adaptability than other species, presumably, in this strata, the species is still able to compete with other species. Besides, the distribution is quite high because the fruit of the species $P$. pinnata is favored by birds so that it is beneficial to spread further and evenly.

\subsection{Floristic Composition of Pole Strata on Pandanus Habitat}

The composition of the pole strata species with the most families in the National Park consists of 22 families of 83 species. In this stratum, the Dipterocarpaceae family consists of more than 14 species, then the list is followed by the Lauraceae family composed of 13 species, followed by the families of Anacardiaceae and Clusiaceae, each of 6 species. On the record, the pandanus family is absent. The list of Quantitative analysis for IVI (pole phase) is presented in Table 4.

Table 4. Quantitative analysis for IVI (pole phase)

\begin{tabular}{llllllll}
\hline \multirow{2}{*}{ No } & Vernacular Name & Scientific Name & Family & $\begin{array}{c}\text { RD } \\
\text { (\%) }\end{array}$ & $\begin{array}{c}\text { RF } \\
\text { (\%) }\end{array}$ & $\begin{array}{c}\text { RDo } \\
\text { (\%) }\end{array}$ & $\begin{array}{c}\text { IVI } \\
\text { (\%) }\end{array}$ \\
\hline $\mathbf{1}$ & Balam merah & Palaquium gutta & Sapotaceae & 7.62 & 4.98 & 4.26 & 16.86 \\
$\mathbf{2}$ & Asam-asam & Garcinia atroviridis & Clusiaceae & 4.63 & 5.40 & 2.98 & 13.01 \\
$\mathbf{3}$ & Buah bunto & Garcinia sp & Clusiaceae & 3.00 & 3.70 & 4.26 & 10.96 \\
$\mathbf{4}$ & Mempening & Quercus lucida & Fagaceae & 3.81 & 3.70 & 2.98 & 10.49 \\
\hline
\end{tabular}




\begin{tabular}{|c|c|c|c|c|c|c|c|}
\hline No & Vernacular Name & Scientific Name & Family & $\begin{array}{r}\text { RD } \\
(\%)\end{array}$ & $\begin{array}{r}\mathrm{RF} \\
(\%)\end{array}$ & $\begin{array}{l}\text { RDo } \\
\text { (\%) }\end{array}$ & $\begin{array}{r}\text { IVI } \\
(\%)\end{array}$ \\
\hline 5 & Medang & Litsea sp1 & Lauraceae & 4.36 & 4.12 & 1.71 & 10.19 \\
\hline 6 & Bengkal timah & $\begin{array}{l}\text { Koordersiodendron } \\
\text { pinnatum }\end{array}$ & Anacardiaceae & 3.27 & 2.85 & 2.13 & 8.25 \\
\hline 7 & Kedundung & Santiria dacryodifolia & Burseraceae & 3.27 & 2.85 & 2.13 & 8.25 \\
\hline 8 & Mahang & Macaranga kingii & Eurphobiaceae & 3.54 & 2.14 & 2.56 & 8.24 \\
\hline 9 & Terap & Artocarpus elasticus & Moraceae & 3.00 & 2.14 & 1.28 & 6.42 \\
\hline 10 & Merpayang & Scaphium macropadum & Malvaceae & 3.00 & 1.28 & 1.71 & 5.99 \\
\hline
\end{tabular}

In the pole strata, Palaquium gutta species with IVI (16.86\%), Garcinia atroviridis with IVI (13.01\%), followed by Garcinia sp with IVI (10.96\%), then Quercus lucida with IVI (10.49\%), Litsea sp1 with IVI (10.19\%), etc. It can be seen that Palaquium gutta species dominate this level followed by species of Garcinia atroviridis and Garcinia sp. Allegedly Palaquium gutta has quite a good adaptability so that this species is more commonly found in stratum areas with high IVI differences because of the ability of this species to adapt better in wet and high humidity environments. Species having the above high and very high IVI in plant ecology are known as exclusive species related to quantitative values in terms of frequency, density, or dominance.

\subsection{Floristic Composition of Tree Strata on Pandanus Habitat}

The composition of the species of tree strata with the most families in the National Park consists of 33 families of 108 species. In this stratum, the Anacardiaceae family has more species consisting of 14 species. Furthermore, the list is followed by the families of Lauraceae and Dipterocarpaceae, each of 12 species, and so on. On the list the pandanus family is absent. The Arecaceae family contains more than 23 species. Furthermore, the list is followed by the families of Pandanaceae, Lauraceae, and Rubiaceae, each of 5 species, followed by the family of Euphorbiaceae 4 species and so on. On the list the pandanus family is absent. The list of Quantitative analysis for IVI (tree phase) is presented in Table 5.

Table 5. Quantitative analysis for IVI (three-phase)

\begin{tabular}{llllllll}
\hline No & Vernacular Name & Scientific Name & Family & $\begin{array}{l}\text { KR } \\
\text { (\%) }\end{array}$ & $\begin{array}{l}\text { FR } \\
\text { (\%) }\end{array}$ & $\begin{array}{l}\text { DR } \\
\text { (\%) }\end{array}$ & $\begin{array}{l}\text { IVI } \\
\text { (\%) }\end{array}$ \\
\hline 1 & Medang labu & Litsea glutinosa & Lauraceae & 4.55 & 3.72 & 1.66 & 9.93 \\
2 & Terap & Artocarpus elasticus & Moraceae & 4.55 & 3.72 & 1.66 & 9.93 \\
3 & Balam merah & Palaquium gutta & Sapotaceae & 4.55 & 3.41 & 1.66 & 9.62 \\
4 & Beyung & Canarium pilosum & Burseraceae & 2.51 & 3.09 & 1.66 & 7.26 \\
5 & Petaling & Ochanostachys amentacea & Olacaceae & 3.42 & 2.77 & 0.83 & 7.02 \\
6 & Mempening & Lithocarpus lucidus & Fagaceae & 2.74 & 2.77 & 0.83 & 6.34 \\
7 & Pengerowon & Hopea mengerawan & Dipterocarpaceae & 1.14 & 1.60 & 3.31 & 6.05 \\
8 & Kedundung & Santiria dacryodifolia & Burseraceae & 2.74 & 2.45 & 0.83 & 6.02 \\
\hline
\end{tabular}




\begin{tabular}{|c|c|c|c|c|c|c|c|}
\hline No & Vernacular Name & Scientific Name & Family & $\begin{array}{r}\text { KR } \\
(\%)\end{array}$ & $\begin{array}{r}\text { FR } \\
(\%)\end{array}$ & $\begin{array}{r}\text { DR } \\
(\%)\end{array}$ & $\begin{array}{r}\text { IVI } \\
\text { (\%) }\end{array}$ \\
\hline 9 & Kelungkung & Shorea retinodes & Dipterocarpaceae & 2.28 & 2.77 & 0.83 & 5.88 \\
\hline 10 & Medang & Litsea $s p$ & Lauraceae & 2.28 & 2.45 & 0.83 & 5.56 \\
\hline
\end{tabular}

Note: $\mathrm{RD}=$ relative density, $\mathrm{RF}$ = relative frequency, $\mathrm{Rdo}=$ relative dominance, $\mathrm{IVI}=$ important value index

In the tree strata the Litsea glutinosa species dominated with the highest IVI (9.93\%), then the Artocarpus elasticus tree with IVI (9.93\%), then two species of Palaquium gutta and Canarium pilosum trees with IVI values $9.62 \%$ and $7.62 \%$ and so on. The species L. glutinosa dominates with the highest number of individuals, this is possible because species can produce many seeds every flowering season. Pole strata up to Litsea glutinosa and Artocarpus elasticus tree strata dominate, and species growth is relatively fast. In the pole and tree strata both species are more likely to be intolerant, besides that they have optimal growth ability. In nature, the family species Lauraceae and Moraceae are found at the height of 35 meters (Lekito et al., 2008).

\subsection{Pandanus Distribution Pattern}

In the seedling and sapling strata there were 5 species of pandanus in BDNP, namely: B. kurzii, B. atrocarpa, P. labyrinthicus, P. furcatus, and P. immersus. Based on the Morisita dispersion index (ID) calculation, the distribution types of the five pandanus species were obtained as presented in Table 6. Based on ID calculations (Table 6), there were two species of pandanus with values greater than one, namely $B$. kurzii and $B$. atrocarpa spread in groups. Most of the research sites are primary forests with high tree density. The results of the analysis of seedling strata vegetation suggest that many numbers of understorey species dominate the area.

Pandanus B. kurzii and B. atrocarpa species are common in swamp habitats with muddy soil and low $\mathrm{pH}$, then $P$. labyrinthicus, $P$. furcatus and $P$. immersus are evenly distributed on loose soil in the hilly area of the region. The possibility of grouping two species of pandanus because it is included in plants that require little light, so it is found in shaded and somewhat shady places. Distribution patterns are closely related to environmental conditions. The organism of a place is interdependent, so it is not bound by opportunity only, and if there is a disruption of organisms and some environmental factors will affect the community (Barbour et al., 1987).

Table 6. Pandanus distribution (Pandanaceae) in BDNP area

\begin{tabular}{llrrl}
\hline Pandanus Species & $\bar{X}$ & \multicolumn{1}{c}{ S $^{\mathbf{2}}$} & ID & Distribution Pattern \\
\hline B. kurzii & 38.45 & 63.00 & 1.63 & Group \\
B. atrocarpa & 32.14 & 40.39 & 1.25 & Group \\
P. furcatus & 22.00 & 8.23 & 0.37 & Evenly Distributed \\
P. labyrinthicus & 27.00 & 14.70 & 0.54 & Evenly Distributed \\
P. immersus & 16.40 & 2.86 & 0.17 & Evenly Distributed \\
\hline
\end{tabular}


The results of the study in the field showed that several species of pandanus distribution in groups (Table 6). Apart from environmental factors and competition, the results are relevant to Barbour et al., (1987) clump plant species tend to have grouped distribution pattern, it because grows and reproduces with seeds falling near the parent or with rhizomes producing vegetative tillers still near the parent. Pandanus is a clumped plant species, clumps of groups tend for grouping distribution patterns to be larger than even and random distribution patterns (Djufri, 2002).

\subsection{Pandanus Association in BDNP}

The association between species is an approach to see whether or not there is an association between pandanus species in BDNP and other species. In this formulation using hypothesis $\mathrm{H}_{0}$ there are no associations and $\mathrm{H}_{1}$ there are associations. The association of several pandanus species with other plants is found in each growth stratum. The results of the calculation and testing of $\mathrm{X}^{2}$, type of interspecific associations recorded only one species which positively associated with one type of pandanus as presented in Table 7. Positive coefficient values (Table 7) indicated although there is no real relationship between one dominant tree species and several species of pandanus, but can still live together and not interfere with each other. Following the opinion of Mueller-Dombois, \& Ellenberg, (1974), that in addition to the influence of the interaction of a community, each plant gives each other a place to live in the same area and habitat.

Table 7. The results of the calculation of association of pandanus species with other plants

\begin{tabular}{llccccc}
\hline No & Associated pandanus species & $\begin{array}{c}\mathbf{X}^{2} \text { table } \\
\mathbf{5 \% )}\end{array}$ & $\mathbf{X}^{2}$ calculation & $\begin{array}{c}\text { Association } \\
\text { Type }\end{array}$ & $\mathbf{E ( a )}$ & $\begin{array}{c}\text { Association } \\
\text { Index (0i) }\end{array}$ \\
\hline 1 & $\begin{array}{l}\text { Benstonea kurzii with Litsea } \\
\text { sp1 }\end{array}$ & 3.84 & $7.87^{*}$ & + & 2.00 & 0.59 \\
\hline
\end{tabular}

Description: +: Positive Association *: Significantly difference with 5\% testing level. the association calculation requirements if IVI plants are more than $10 \%$ in a phase

Species association does not always produce positive relationships. Plant species that have a high and dominant attendance frequency do not always give a high positive association value with other species. Furthermore, species that have low attendance frequency do not always give negative associations with other species. The calculation of the association of pandanus species with other plants (Table 7) is known that only Benstonea kurzii is positively associated with Medang (Litsea sp1). The association determination with contingency tables is continued to test the association index value so that it is known whether the positive association in the matrix also shows a high association index value. On the contrary, for negative associations, the results of the calculation of the association index positively reinforce the conclusions of the count of the contingency table that generally plant species in BDNP show tolerance of living together in the same area, or there are mutually beneficial relationships. 
Medang (Litsea sp1) was found abundantly in the field with a density of 11.43 ind/ha and an IVI value of $10.19 \%$. It is suspected that Medang species are positively associated with pandanus, although the association level is low. Positive associations indicate that there are right conditions for one species or both species. In heterogeneous forest environments, associations originate from a similar adaptation and response to the environment of some species (Kusmana, 1997). Negative associations occur in pairs of other species, the presence of individual different species is indicative of interactions that are destructive or detrimental to one or two of the species concerned. In a heterogeneous environment, negative associations reflect the adaptation or individual response of different species of plants to environmental factors (Kusmana, 1997). The results of the association index calculation reinforce the conclusions of the $2 \mathrm{x} 2$ contingency table calculation, that generally, the constituent species of the pandanus vegetation community show mutually beneficial relationships with other species even though the association level does not occur in any other plant species. Beyond the influence of the interaction of a community, each grows to give each other a place to live in an area and habitat together. Community integrity is a well-formed phenomenon; there is tolerance of togetherness so that a degree of cohesiveness is formed (MuellerDombois, \& Ellenberg, 1974; Barbour et al., 1987).

\section{Conclusion}

Floristic composition in the pandanus habitat is particularly found in the seedling strata consisting of 106 species, and the more common species are Palaquium gutta with a value of IVI (14.53). The results of the analysis of the dispersion of pandanus species found that two species of pandanus spread in groups, and three species of pandanus spread evenly. Only one pandanus species is associated with a tree species, Benstonea kurzii, with Litsea sp1. The study concluded that the population of pandanus in BDNP was tiny compared to other types of plants around it. As a concern, the conservation of pandanus species in the BDNP area and the rehabilitation of tropical forests will be crucial in preserving biodiversity.

\section{References}

Barbour. G.M., Busk. J.K., \& Pitts. W.D. (1987). Terrestrial Plant Ecology. The Benyamin/Cummings Publishing Company, Inc: New York.

Djufri. (2002). Penentuan Pola Distribusi, Asosiasi, Dan Interaksi Spesies Tumbuhan Khususnya Padang Rumput di Taman Nasional Baluran, Jawa Timur. Biodiversitas 3(1): 181-188.

Ismail. M.H., Fuad. M.H.A, Zaki. P.H., \& Jemali. N.J.N. (2017). Analysis of Importance Value Index of Unlogged and Logged Peat Swamp Forest in Nenasi Forest Reserve, Peninsular Malaysia. Bonorowo Wetlands 7(2): 74-78. 
Kusmana. C. (1997). Metode Survey Vegetasi. IPB Press: Bogor.

Keim. A.P. (2011). New Variety, Records \& Discoveries Of Some Species of Pandanus (Pandanaceae) in Sumatra and Kalimantan, Indonesia. Reinwardtia 13(3): 255262.

Lekito.K., Matani. O.P.M., Remetwa. H., \& Heatubun. C.D., (2008). Keanekaragaman Flora Taman Wisata Alam Gunung Meja - Papua Barat (Jenis-jenis Pohon Bagian1). Balai Penelitian Kehutanan Manokwari: Manokwari.

Ludwig. J.A., \& Reynolds. J.F. (1988). Statistical Ecology. 2nd ed. Edward Arnold Publisher: London.

Mairida. D., Hariyadi. B \& Saudagar. F. (2014). Kajian Etnobotani Peralatan Rumah Tangga Suku Anak Dalam di Taman Nasional Bukit Duabelas Kabupaten Sarolangun, Jambi. Biospecies 7(2): 68-75.

Mueller-Dombois. D., \& Ellenberg. H., (1974). Aims and Methods of Vegetation Ecology. John Wiley and Sons Publisher: New York.

Netto. S.P., Amaral. M.K., \& Coraiola. M. (2015). A New Index for Assessing the Value of Importance of Species-VIS. Annals of The Brazilian Academy of Sciences 87(4): 2265-2279.

Pereki. H., Wala. K., Thiel-Clemen. T., Bessike. M.P.B., Zida. M., Dourma. M., Batawila. K., \& Akpagana. K. (2013). Woody Species Diversity and Important Value Indices in Dense Dry Forests in Abdoulaye Wildlife Reserve (Togo, West Africa). International Journal of Biodiversity and Conservation 5(6): 358-366.

Prasaja. D., Muhadiono \& Hilwan. I. (2015). Etnobotani Pandan (Pandanaceae) di Taman Nasional Bukit Duabelas Jambi. Berita Biologi 14(2): 121-129.

Rachma. R.A., Hendrian \& Azrianingsih. R. (2017). The Analysis of Pandanus Relationship of Purwodadi Botanical Garden Collections Based on Morphological Character and Molecular Marker (trnL and trnL-F). Research Journal of Life Science 4(2): 129-141.

Rahayu. S. E \& Handayani. S. (2008). Keanekaragaman Morfologi Dan Anatomi Pandanus (Pandanaceae) di Jawa Barat. Journal of. Vis Vitalis 01:2.

Riberu. P. (2002). Pembelajaran Ekologi. Jurnal Pendidikan Penabur 1(1): 130-132.

Setiawan. 0 \& Narendra. B. H. (2012). Ecology Of Medicinal Tree, Strychnos ligustrina Bl. in Dompu District, West Nusa Tenggara Province. Journal of Forestry Research 9(1): 1-9. 
Setyowati. F.M. (2003). Hubungan Keterikatan Masyarakat Kubu Dengan Sumber Daya Tumbuh-Tumbuhan di Cagar Biosfer Bukit Duabelas, Jambi. Biodiversitas 4(1): 47-54.

Susilowati. A., Rachmat. H.H., Elfiati. D., \& Hasibuan. M.H. (2019). The Composition and Diversity of Plant Species in Pasak Bumi's (Eurycoma longifolia) Habitat in Batang Lubu Sutam Forest, North Sumatera, Indonesia. Biodiversitas 20(2): 413418.

Sutomo \& Fardila. D. (2013). Autekologi Tumbuhan Obat Selaginella doederleinii Hieron di Sebagian Kawasan Hutan Bukit Pohen Cagar Alam Batukahu, Bedugul Bali. Jurnal Penelitian Hutan dan Konservasi Alam 10(2), 153-161.

Tulalessy. A. H. (2012). Potensi Flora Di Kabupaten Seram Bagian Barat. Journal of Ekosains 1(1): 1-5.

Wiriadinata. H \& Setyowati. F.M. (1998). Kajian Pemanfaatan Tumbuhan oleh Suku Anak Dalam di Cagar Biosfer Bukit Duabelas, Jambi. Di dalam: Puslit Biologi. Prosiding Seminar Nasional Etnobotani III. Bogor: LIPI. Hal 274-283. 